\title{
Sosyal Sermaye ve Armağan Ekonomisi Üzerinden Sosyal Medya ve Stalk Olgusu: Instagram Üzerinden Bir İnceleme
}

\author{
Rabiya Saltık \\ Öz
}

Gündelik hayatın önemli bir parçası haline gelen sosyal medya insan hayatına pek çok yeni kavram kazandırmıştır. Bu kavramlardan biri de stalktır. Stalk, sosyal medya kullanıcıları arasında fenomenleşen dijital iz sürmeye yönelik bir davranış biçimidir. Stalklama terimi bugün internet ortamından başkalarının hesaplarını takip etme, inceleme, başkalarının hayatlarına ve kişisel özelliklerine dair ayrıntılı bilgiler edinme anlamlarında kullanıır. Sosyal paylaşım ağlarının stalk evreninde kullanıcılar sosyal, kültürel ve ekonomik sermaye biçimlerinden herhangi birini kurma fırsatı bularak sosyal ağlar üzerinden sürdürülen armağan ilişkilerine hayat vermektedir. Bu çalışmada birer politikacı, sanatçı, aktivist, ünlü ve fenomen olmak üzere Instagram hesaplarını farklı amaçlarla kullanan beş ayrı hesap katılımcı gözlem yöntemiyle gözlemlenmiş ve sosyal sermaye ve armağan teorilerinden yola çıkılarak stalk üzerinden eleştirel bir değerlendirme yapılmıştır. Çalışma sonucunda sosyal medya etkileşimlerinin stalk evreninde kullanıcıların sadece demokratik haklar bağlamında sosyal, kültürel ve ekonomik sermayelerini güçlendirmedikleri aynı zamanda gösteri üzerinden ilerleyen bir sosyal sermaye ile var oldukları görülmüş ve sosyal paylaşım ağları üzerinden ilerleyen armağan ilişkilerinin eleştirel bir değerlendirmesi yapılmıştır.

Anahtar Kelimeler: Sosyal Medya, Stalk, Sosyal Sermaye, Armağan Ekonomisi, Instagram.

Atıf: Saltık, R. (2018). Sosyal Sermaye ve Armağan Ekonomisi Üzerinden Sosyal Medya ve Stalk Olgusu: Instagram Üzerinden Bir İnceleme. Akdeniz Üniversitesi İletișim Fakültesi Dergisi,

(AKiL) Aralık (30), s. 345-363

1 Öğr. Gör., İzmir Kavram Meslek Yüksekokulu Radyo ve Televizyon Programcılığı Programı, rabiya.saltik@ kavram.edu.tr, ORCID Numarası: 0000-0003-4378-3490. 


\title{
Social Media and Stalk Current On Social Capital And Gift Economy: A Research On Instagram
}

\begin{abstract}
Social media, which has become an important part of everyday life, has brought many new concepts to human life. One of these concepts is stalk. Stalk is a behavioural approach for digital tracking among social media users. The term stalking is used today in order to refer to the acts like following others' accounts on the internet environment, and examining and getting detailed information about their lives and personal characteristics. In the stalking universe of social networking networks, users have the opportunity to establish any social, cultural, and economic capital forms, and bring to life the gift relations that are carried out on social networks. In this study, five different accounts that use an Instagram account for different purposes such as politicians, artists, activists, celebrities and phenomena were observed by participant observation method, and a critical evaluation was made over stalk on the basis of the social capital and gift theories. As a result of the study, it was observed that social media interactions did not only strengthen the social, cultural and economic capitals in the context of democratic rights in the stalk universe, but also existed with a social capital advancement on the demonstration and a critical evaluation of the gift relations that were progressing through social networks.
\end{abstract}

Keywords: Social Media, Stalk, Social Capital, Gift Economy, Instagram. 


\section{Giriș}

nsanoğlunun var olduğu ilk günden bugüne dek değişmeyen şey iletişimin varlığıdır.

İletişim; insanlığın ilk gününden itibaren yaşamların birer parçası olarak var olmuş

olsa da zamana göre değişim göstermiştir. Mağara duvarlarına çizilen resimlerle başlayan iletişim serüveni bugün teknolojinin olanaklarıyla bambaşka bir noktaya ulaşmıştır. Teknoloji aracılı iletişim ise toplumsal değişimi beraberinde getirmiştir. Özellikle 1970'li yıllardan itibaren yaşanan iletişimsel dönüşüm; "enformasyon toplumu" adı altında yepyeni bir topluma işaret eden, öncekinden tamamıyla farklı yeni bir düzenin varlığını tartışmaya açmıştır. 1990'ı yıllarda internetin insan hayatına girmesi ve 2000'li yıllarda tanıdığımız Web 2.0 teknolojisi ile iletişimsel dönüşümün öncekilere oranla büyük bir sıçrama yaptığı rahatlıkla söylenebilir. Öyle ki Web 2.0 teknolojisi daha önce medyanın salt tüketicisi olan geniş yığınları potansiyel birer üretici haline getirmiş ve kullanıcı türevli içerikler ile yeni medya platformları adeta insanın öz benliğinin sunulduğu önemli bir kimlik aracı haline gelmiştir. Bu iletişimsel dönüşümün en etkili anahtarı şüphesiz sosyal medya olmuştur.

Dünyanın dört bir köşesinden milyonlarca insanı bir araya getiren sosyal medya platformları, kullanıcı tabanlı bir medya ortamı olarak etkileşimli iletişimi mümkün kılmanın yanı sıra sanal bir topluluk olma hissi de vermektedir. Sosyal medya platformları kullanıcılar tarafından kimi zaman kolay ve hızı bir iletişim aracı, kimi zaman ifade özgürlüğünün sağlayıcısı, kimi zaman ise kişisel benliği sunmanın ya da başkalarının hayatları ve benliği ile ilgili bilgileri edinmenin mecrası olarak kullanılmaktadır. Sosyal medya platformları aracılığıyla kendisini diğer kullanıcılara seyirlik nesne olarak sunan bireyler; aynı zamanda başkalarının seyirlik paylaşımlarını gözetleyen konumuna gelmektedir. Günümüzde mahremiyete dair tüm niteliklerin yok sayıldığı bu mecralardan en yaygın olanlarından biri de şüphesiz Instagram'dır. Fotoğraf üzerinden gelişen görsel kültürel formların inşa edildiği mecralardan biri olarak Instagram; her yaştan insanın kullanıcı olarak yer aldığı fenomen bir sosyal medya platformudur.

Bu çalışmada son yıllarda sosyal medya platformlarıyla insan hayatına giren ve özellikle de Instagram'la birlikte yaygınlaşan stalk terimi sermaye ve armağan ekonomisi teorileri üzerinden tartışılacaktır. Sosyal medya platformlarında bir kişinin bir başka kişiyi araştırması, gözetlemesi, paylaşımlarını incelemesi anlamına gelen stalk; bu çalışmanın çıkış noktasını oluşturmaktadır (Cumhuriyet 2016). Çalışmanın amacı sosyal medya kullanıcılarının stalk üzerinden değişen iletişimini armağan ekonomisi ve Bourdieu'nun ortaya attığı sermaye teorisi üzerinden irdelemek ve tartışmaya açmaktır. Kullanıcıların diğer kullanıcıların karakterlerine, niteliklerine vb. tüm sermaye verilerine dair bilgileri stalk yoluyla edindikleri varsayımından yola çıkılarak yürütülecek çalışmada; sosyal medyada bir davranış biçimi olarak var olan stalkın hangi amaçlarla kullanıldığı, "gify economy" (armağan ekonomisı) olarak adlandırılan armağanlaşma teorisinin ve Bourdieu'nun ortaya attığı ekonomik, kültürel ve sosyal sermaye kavramlarının stalk ile ilişkisinin kapsamına yanıt aranacaktır. Kullanıcıların kendi sosyal, kültürel ve ekonomik sermayelerini kurmak amacıyla sosyal medyanın armağan ekonomisine nasıl ayak uydurduğu stalkerlık üzerinden sorgulanacaktır. 
Bu amaçla yürütülecek çalışmada ilk olarak stalk kavramı ve kökeni tanımlanacak, ardından Bourdieu'nun ortaya koyduğu sermaye teorisi açıklanarak sosyal medya ve sermaye ilişkisi açıklanacaktır. Daha sonra armağan ekonomisi kavramı tanımlanarak sermaye ve stalk ile ilişkisi açımlanacaktır. Çalışmanın kuramsal zemininin tamamlanmasının ardından sermaye ve armağanlaşma teorileri üzerinden sosyal medya ve stalk olgusunu tartışabilmek için Instagram üzerinden bir inceleme yapılacaktır. Bu amaçla Instagram hesabını farklı amaçlarla kullanan beş ayrı hesabın son üç ayda paylaştığı fotoğraflar katılımcı gözlem yöntemiyle izlenecek ve genel bir değerlendirme yapılacaktır. Katılımcı gözlem yöntemiyle incelenecek hesaplar seçilirken sırasıyla tanınmış-popüler bir politikacı olma, sanat dünyasının önemli isimlerinden biri olma, aktivizm çağrısı yapan bir hesap niteliği taşıma, tanınmış ve yaşam tarzıyla imrenilen bir ünlü olma ve yaptığı paylaşımlar ile sosyal medyada fenomen haline gelme şeklindeki beş ayrı kıstas göz önünde bulundurulacak ve kullanıcıların sosyal medya aracılığıyla sürdürdüğü sosyal sermaye bağları ve armağan ilişkisi stalk bağlamında tartışmaya açılacaktır.

Stalk kavramı son yıllarda hayatımıza giren yeni bir terimdir ve bu konuda yapılmış çok fazla çalışma bulunmamaktadır. Öte yandan çalışma; teknoloji aracılı iletişim ortamında bireylerin kendilerini ve başkalarını algılama, merak etme ve takip etme biçimleri üzerinden sanallaşan iletişim sürecini sermaye ve armağan ekonomisi üzerinden ele almayı amaçlamaktadır. Bu bağlamda ilk olarak çalışmanın temelini oluşturan stalk terimini detaylandırmak yerinde olacaktır.

\section{Stalk ve Stalklama Kavramları}

Dilimize İngilizceden geçmiş olan stalk kelimesi Cambridge Dictionary'de peşine düşmek, gizli gizli izlemek; avına sinsice yaklaşmak, kasıla kasıla yürümek; azametle/ çalım satarak yürümek anlamlarına gelmektedir. Yine aynı sözlükte stalker terimi takip eden kimse, gizlice izleyen kimse olarak tanımlanmaktadır (dictionary.cambridge. org). Stalker terimi Oxford Dictionary'de ise istenmeyen, obsesif bir dikkatle birini rahatsız etmek, tacizde bulunmak ve sıkıntı vermek şeklinde tanımlanmaktadır (oxforddictionaries.com).

Stalklama kavramı dijital teknolojiler öncesinde de kullanılan bir kavram olup birini saplantılı bir biçimde izleme, takip etme ve rahatsızlık yaratma anlamında kullanılmaktadır. Geleneksel stalklama ilk kez 1990'da ABD'de bir aktrisin saplantılı bir hayran eliyle öldürülmesinin ardından suç olarak kabul edilmiştir (Heinrich 2015, s. 16). Geleneksel stalklamadan farklı olarak siberstalklama bilgisayar tabanlı iletişim teknikleriyle tekrarlanan ve istenmeyen temasları ifade etmektedir. Siberstalklama tanımı için temel kriter stalklamadan etkilenenler arasında kaygıya yol açmasıdır (Dreßing, Klein, Bailer, Gass, ve Gallas 2009, s. 834). Siberstalker (cyberstalker) Hitchcock'a göre (2006, s. 157) en basit tanımlamayla başkalarının çevrimiçi faaliyetlerini izleyen ya da gözleyen kişidir. Siberstalklama (cyberstalking) terimi "takipçinin birini taciz etmek için yeni iletişim teknolojilerini kullandığı bir takip türü” anlamındadır. Stalklama faaliyetinin internet ortamında gerçekleştirilen biçimine verilen siberstalklama tanımlaması bugün 
ise farklı bir anlamda kullanılmaktadır. Siberstalklama bugün internet ortamından başkalarının hesaplarını takip etme, inceleme, başkalarının hayatlarına ve kişisel özelliklerine dair ayrıntılı bilgiler edinme anlamlarında kullanılır. Üstelik bu tanımlama suç ve davranış bozuklukları ile ifade edilen fiziksel stalklamanın aksine kabul edilebilir ve olağan davranış biçimini ifade eder (Akmeşe ve Deniz 2017, ss. 24-25).

Kullanıcıların tanıdığı ya da tanımadığı kişilerin profil hesaplarında dolaşarak iz sürmesi basitçe teknolojik bir olanak üzerinden açıklanamaz. Öyle ki siberstalk üzerine çalışmalar yapan Basu ve Jones (2007; Heinrich 2015, s. 30) internet kullanıcılarının siber alana kendi istekleriyle girdikleri ve bu sebeple stalklanmayı kabul etmeleri gerektiğini ifade ederek siberstalk mağdurlarının kabul edilmiş davranış biçimi sergilediklerini destekleyen fikirler sunmaktadır. Gerçekten de çeşitli sosyal medya platformlarında kişisel hesabı bulunan kullanıcılar profil hesapları aracılığıyla gözetlendiklerinin bilincindedir. Öyle ki kullanıcılar bütün paylaşımlarını takip edildiğinin bilincinde olarak yapmakta hatta bunun da ötesinde takipçilerine ya da sosyal medya kullanıcılarına kendisiyle ilgili sunmak istediği iletileri yaptıkları paylaşımlar aracılığıyla iletmektedir. Teknolojiyi kullanan her birey kişisel bilgilerini, konumunu, arkadaş ayrıntılarını ve çok daha fazlasını içerebilen "dijital ayak izlerini" stalkerları için geride bırakmaktadır (Perry 2012, s. 8). Öte yandan aynı bireyler başka sosyal medya kullanıcılarının hesaplarını gizliden ya da açıktan takip ederek yani dijital iz sürerek stalker olma rolünü de üstlenmektedir. Bu stalklama evreni kullanıcıların ilgisini çekecek paylaşımlar olduğu sürece devam etmektedir. O halde kullanıcıların niçin stalklama faaliyetinde bulunduğunu ya da kendisini stalklayan diğer kullanıcılara hangi bilgileri sunduğunu sermaye teorisi üzerinden açımlamak doğru olacaktır.

\section{Sermaye Kavramı, Sermaye Türleri ve Sosyal Sermaye}

Sermaye kavramı Coleman, Putnam gibi pek çok isim tarafından ele alınmış bir konu olsa da bu kavrama en büyük katkıları Pierre Bourdieu sağlamıştır. Bourdieu, ekonomik, kültürel ve sosyal sermaye olmak üzere toplam üç sermaye türü olduğunu ifade eder. Bourdieu'nun sermayenin ilk biçimi olarak tanımladığı ekonomik sermaye maddiyata dönüşebilen veya mülkiyet olarak muhafaza edilebilen sermaye türüdür. Sermayenin ikinci biçimi olan kültürel sermaye eğitimle kazanılmakta ve uygun koşullar sağlandığında ekonomik sermayeye dönüşebilmektedir. Bourdieu'nun sermayenin son biçimi olarak tanımladığı sosyal sermaye ise bireyin sahip olduğu toplumsal ağlar aracılığıyla oluşan ve belirli durumlarda ekonomik sermayeye dönüşebilen sermayedir (Bourdieu 2010, s. 49). Bourdieu daha sonraki çalışmalarında siyasal sermaye, hesaplama sermayesi ve sembolik sermaye gibi yeni kavramlardan da bahsederek sermaye türleri arasında değişim olabileceğini ifade eder (Şan ve Çiftçi 2017, s. 359).

Bir kavram olarak sosyal sermaye 21.yüzyılın ortalarına doğru literatür alanına girmiş olsa da 1960'lı yıllardan itibaren tartışılmaya başlamıştır. Modern toplumun bireyci anlayışı sebebiyle zayıflayan sosyal bağlar ve bunun getirdiği yabancılaşma olgusu sosyal sermaye tartışmalarının gündeme gelmesine sebebiyet vermiştir (Yarcı 2011, s. 126). Temple’a göre (2000, s. 23; Boz vd. 2017, s. 634) basit bir tanımla sosyal sermaye; 
"en az iki kişi arasında, güvene dayalı bir şekilde kurulabilen iletişim imkanıdır." Bourdieu ve Wacquant sosyal sermayeyi "bir bireyin ya da bir grubun kalıcı bir ilişkiler ağına az çok kurumlaşmış karşılıklı tanıma ve tanınmalara sahip olması sayesinde elde ettiği gerçek ya da potansiyel kaynakların toplamı" olarak tanımlamaktadırlar (aktaran Phua, Jin ve Kim 2017, s. 116). Coleman sosyal sermayeyi üretken faaliyeti kolaylaştıran bir dizi insan ilişkisine benzetmiştir, çünkü insanlar bu ilişkileri hedeflerine ulaşmak için kaynak olarak kullanmaktadır (aktaran Phua ve Jin 2011, s. 505). Görüldüğü üzere sosyal sermaye üzerine pek çok tanımlama yapılmış olsa da her tanımlamada ortak temel bireyler arasındaki iletişim bağlarının varlığı olmuştur.

Sosyal sermaye için Bourdieu (1977, s. 503; aktaran Babacan 2012, s. 71) şöyle bir tanımlama yapmaktadır:

"Gerekli olduğunda faydalı destekler sağlayan toplumsal ilişkilerin sermayesidir. Herhangi biri toplumsal açıdan önemli konulara, örneğin siyasi bir kariyer gibi aynı zamanda para değeri de olan konumlara sahip olan müşterilerinin ilgisini çekmek istediğinde çoğu zaman vazgeçilmez olan saygınlığın ve onurluluğun sermayesidir."

Bourdieu'ya göre (aktaran Ünal 2004, s. 117) sosyal sermayeye sahip olmak, ilişkiler kurmayı ve sürdürmeyi kapsayan sosyalleşme çabalarına bağlıdır. Ekonomik ve kültürel sermayenin aksine sosyal sermaye belirli bir hayat tarzına yol açmaktan daha ziyade sosyal çevrelere girmede işlev sağlayan önemli bir aracıdır. Sosyal sermaye toplumsal ilişkilerden oluşan, belirli şartlar içinde ekonomik sermayeye dönüşerek bir soyluluk belirtisi şeklinde kurumsallaşabilecek olan sermaye türüdür (Bourdieu 2010, s. 2-3). Bourdieu sermayeyi üretim ve yeniden üretim süreci olarak tanımlayarak onu bir "güç" unsuru olarak kabul etmektedir (aktaran Babacan 2012, s. 72). Nitekim bu güç unsuru toplumsal yaşamda pek çok avantajla özdeşleştirilebilir. Sosyal sermaye üzerinde çalışan Ellison ve diğerleri (2014) de sosyal sermayenin olumlu sonuçlarını yani kazandırdığı güç unsurlarını artan benlik saygısı, sivil katıım ve yaşam memnuniyeti olarak açıklamaktadır (Phua, Jin ve Kim 2017, s. 116).

Sermaye kelimesi kulağa ekonomik bir terimi çağrıştırıyor gibi gelse de Bourdieu bu kavramı farklı bir anlamda kullanmaktadır. Ona göre sosyal dünyayı kavrayabilmenin anahtarı sermaye terimini ekonomik anlamının ötesinde kullanmaktır. Sosyal sermaye, grup üyeliği üzerinden, birinin ihtiyaç durumunda potansiyel olarak faydalanabileceği ağ ilişkileri anlamına gelmektedir. Bourdieu, sosyal sermaye ile kaynaklara eşitsiz ulaşım problemini "alan" ve "habitus" kavramları üzerinden açıklamaktadır. Habitus, özel toplumsal koşullara maruz kalınarak algılanan ve içerisinde hareket edilen dünyanın aracılığıyla oluşan yatkınlıklar sistemine işaret etmektedir. Diğer yandan insanların edindikleri yatkınlıklar sistemi toplumda işgal ettikleri konuma, yani özel sermaye durumlarına bağımlıdır. İnsanlar mevcut sermayeleri aracılığıyla mikro alanlarda güç için rekabet halinde olmaktadır. Sonuç olarak bireylerin cinsiyet, etnik köken ve toplumsal sınıf üzerinden ekonomik sermayelerinin yanı sıra sosyal ağları da tabakalaşmakta ve alan içindeki kaynaklara erişimi belirleyen yatkınlıklar sistemi ortaya çıkmaktadır (Yalçın 2015, s. 46-47). 
Sosyal sermayeye toplum ve birey için sunulan faydalar zeminiyle yaklaşan pek çok sosyal bilimcinin tersine Bourdieu, kendi sosyal sermaye felsefesiyle eleştirel bir perspektif sunmaktadır. Sosyal sermayeyi toplumsal eşitsizliği getiren bir olgu olarak gören Bourdieu, bireylerin çıkarları için yatırım stratejisi anlayışıyla hareket ederek bağlantılarını kullanmasının toplumsal hiyerarşiyi gerektirdiğine işaret etmektedir. Dolayısıyla Bourdieu'nun yaklaşımı sosyal sermayeyi ezilenler için karanlık, ayrıcalıkıı olanlar için ise aydınlık bir olgu olarak tanımlamaktadır. Putnam'ın tersine sosyal sermayeyi kolektif bir kaynak olarak görmeyen Bourdieu, yalnızca diğer sermaye türleriyle öne çıktığını savunduğu sosyal sermayeyi kişiler arasındaki eşitsizlikleri daha da arttıran bir olgu olarak kabul etmektedir (Yarcı, 2011, ss. 132-133).

\section{Sosyal Medya, Sosyal Sermaye ve Stalk}

Sosyal medya, Web 2.0'ın teknolojik temelleri üzerine kurulu, kullanıcı tarafından oluşturulan içeriğin oluşturulmasına ve değiştirilmesine izin veren internet tabanlı uygulamalar grubudur (Kaplan ve Haenlein 2010, s. 61; Sun ve Shang 2014, s. 334). Mobil teknolojiler ile kullanımı artan sosyal medya platformları bireylerin kimlikleri konusunda bilgi edinmenin mecrası haline gelmiştir. Duggan'a göre (2015), insanların internet sosyal bağlantılarına istedikleri zaman ve herhangi bir yerden ağa bağlı mobil cihazları aracılığıyla kolayca erişebildikleri Web 2.0 etkinliğine sahip bilgisayar aracılı iletişim çağında, sosyal paylaşım ağları giderek artan bir şekilde sosyal sermayenin yaratılması ve sürdürülmesi için önemli bir platform haline gelmektedir. Sosyal ağlar, insanları çevrimdışı iletişimde de var olan aile ve arkadaşlara bağlarken, aynı ilgi alanlarını paylaşan farklı coğrafi konumlardan başkalarıyla etkileşimde bulunarak çevrimiçi ağların genişletilmesini de sağlamaktadır (Phua, Jin ve Kim 2017, s. 116).

İnternet, sosyal sermayenin birikimini, işleyişini, yönetimini ve kapitalizasyonunu büyük ölçüde kolaylaştırmıştır. Wellman, Quan-Haase, Witte ve Hampton da (2001), insanların çevrimiçi etkileşimlerinin yüz yüze iletişimi desteklediğini ve yoğun internet kullanımının gönüllü ve politik organizasyonlara artan katılımla ilişkili olduğunu savunmuştur (Phua ve Jin 2011, s. 505). Öte yandan Nie ve Hillygus (2002) yaptıkları araştırmayla interneti olası yeni bir sosyal aktivite alanı olarak görmemektedir. Çünkü çevrimiçi olarak oluşabilecek yeni sosyal sermayenin bir ölçüsü yoktur. Bu sebepten ötürü, çevrimiçi sosyalleşmenin çevrimdışı olarak kaybedilen sosyalleşmeyi asla telafi edemeyeceği kanısındadırlar (Williams 2006, s. 596).

Ellison ve Diğerleri (2011) sosyal sermaye faydalarını elde etmek için sosyal ağlarda bireylerin bir dereceye kadar kendilerini ifşa etmek zorunda olduklarını ifade etmektedir. Buna göre gizlilik hakkında daha fazla endişe duyan ya da bir ağ aracılığıyla bilgi paylaşımı konusunda güvensizlik hisseden kişiler, kendilerini bir derinlik ve özgünlük düzeyi ile ifade edemeyecektir (Shane-Simpson, Manago, Gaggi ve Gillespie-Lynch 2018, s. 278). Buna göre sosyal medya hesaplarını herkese açık olarak kullanarak stalklanmaya açık hale gelen kullanıcılar, sosyal sermayenin faydalarını gizli hesap kullananlara oranla daha fazla deneyimlemektedir. Öte yandan sosyal sermayesini kurmak için gizliliği geri plana atan bu kullanıcılar mahremiyete dair kuralları çiğnemek 
durumunda kalmaktadır. Instagram'ın mahremiyet alanına olan müdahalesi onu sosyal sermayeden en üst seviyede yarar sağlayan bir sosyal paylaşım ağı haline getirmektedir. Bireyler kendilerine fayda sağlayacak sosyal sermaye ilişkilerine erişmek adına en mahrem alanlarını dahi takipçileriyle paylaşmaktan geri kalmamaktadır.

Sosyal sermaye üzerinde çalışan pek çok araştırmacı sosyal sermayeye olumlu bir olgu olarak yaklaşırken Pierre Bourdieu'nun eleştirel bir yaklaşım benimsediğini söylemiştik. Bourdieu'nun eleştirel sosyal sermaye perspektifi sosyal medya üzerinden ele alındığında Bourdieu'nun sermaye ile ilgili görüşlerini haklı çıkaran pek çok şey söylenebilir. Bourdieu'ya göre sosyal ağlar sadece sosyal sermayenin neleri ifade ettiği ile sınırlı değil, aynı zamanda bireylerin arzuladıkları sonuçlara erişmek için sosyal sermayeyi nasıl kullandığını açıklamak için de önemli bir anahtardır (Babacan, 2012:89). Öyle ki sosyal medya kullanıcılarının çoğu sosyal medya platformlarını sosyal ilişkilerini güçlendirmenin ötesinde bireysel benliğini sunmak için kullanmaktadır.

Yeni iletişim teknolojilerinin insan hayatına kazandırdığı pek çok avantaj olsa da önemli kayıplar ve kaygılar yarattığı da görülmektedir. Modern toplumlarda şehir hayatının karmaşasının bireyler arasındaki iletişim bağının kopmasına, samimiyetin giderek ortadan kalkmasına sebep olduğu gözlemlenmektedir. McPerson ve Putnam gibi araştırmacılar bu toplumlarda iletişim bağlarının giderek azaldığını ve sosyal sermaye bağlarında da düşüş yaşandığını öne sürmektedir (Ling 2008). Sosyal medyada yaptıkları paylaşımlar ile bireyler dış görünüşlerinin, hoşlandıkları şeylerin, hobilerinin, mesleklerinin, aile bağlarının ya da diğer duygusal bağlarının özetle özel hayatlarına dair tüm bilgilerini diğer kullanıcılara sunarak kendi sosyal sermayelerini oluşturmakla birlikte esas olarak diğer kullanıcılara kendi öz benlikleri hakkında fikirler sunmaktadır.

Sosyal paylaşım ağlarında temsil edilen sosyal sermaye çalışmanın temelini oluşturan stalk çerçevesinde düşünüldüğünde, sosyal medyayı kendi sosyal sermayelerini oluşturmak amacıyla kullanan bireylerin pek tabii stalklanma arzusunda olduğu söylenebilir. Amacı sosyal ağlar aracılığıyla sosyal sermaye bağlarını güçlendirmek olan bireyler başka kullanıcılara kendi sosyal sermayesinin bilgisini stalk ile ulaştırmaktadır. Öte yandan aynı kullanıcılar merak ettiği ya da "keşfet" portalında karşılaştığı kullanıcıların sosyal sermaye bilgisine erişebilmek için o kullanıcıların stalkerı olmaktadır.

Esasında sosyal sermaye bağlarını kurmak ve güçlendirmek isteyen neredeyse her bireyin bugün sosyal medyada var olması zorunlu hale gelmiştir. Bugün sosyal medya hesabı olmayan birey sayısı oldukça azdır. Ünlü ya da ünsüz fark etmeksizin her birey sosyal medya hesapları aracılığıyla sosyal sermayesini oluşturmaktadır. Sosyal medyayı bireysel olarak kullanmayan ünlü kimseler de çoğunlukla sosyal medya uzmanları aracılığıyla resmi bir hesap üzerinden sosyal sermayesini güçlendirmeyi denemektedir. Bir müzisyen vereceği konserlerin, bir siyasetçi fikir ve düşüncelerinin, bir gezgin gezip gördüğü yerlerin bilgisini sunan paylaşımlar aracılığıyla sosyal ağlarda kendisiyle aynı ilgiye sahip diğer kullanıcılara/stalkerlara perde aralamakta ve bu şekilde etkileşime dayalı bir bağ kurulabilmektedir. 
Sosyal paylaşım ağlarında sürdürülen sosyal sermayenin ne denli etkin olduğu konusu ise tartışmaya açıktır. Yeni medyanın sağladığı tüm teknolojik olanaklar sosyal sermaye için olumlu gibi görünse de pratikte her zaman çok olumlu tablolar ortaya çıkmamaktadır. Gerçek hayatta kurulan sosyal bağların her zaman sosyal medya aracılığıyla da kurulabileceğini söylemek doğru bir yaklaşım olmayacaktır. Bir politikacının sosyal medya hesabında paylaştığı harekete geçirici bir fotoğraf ya da video on binlerce hatta milyonlarca kullanıcı tarafından görülmekte ancak; politikacıyla iletişime geçme ya da çağrıya ayak uydurma konusunda tüm imkanları olduğu halde kullanıcıların çok azı gerçekten sosyal bağlar kurmayı denemektedir. Yine politikacının paylaştığı video milyonlarca insan tarafından görülse de çok daha azı tarafından beğenilmekte ve onaylanabilmektedir. O halde sosyal ağlar aracılığıyla kurulan sosyal bağların bazen yüzeysel bir seviyede kaldığı söylenebilir. Özellikle insanların fotoğraf tabanlı sosyal paylaşım ağları aracılığıyla sürdürdüğü sosyal bağların temelinde bu bağların pekiştirilmesinden ziyade kendi öz benliğini tatmin etme, saygınlık ve beğeni kazanma, fiziksel ya da zihinsel benlik ile kabul görme ve onaylanma hususundaki beklentiler baskın olmaktadır. Bu durum ise gösteri üzerinden ilerleyen sosyal sermayeye işaret etmektedir. Guy Debord (1996, s. 14); gösteriyi "kişiler arasında var olan ve imajların dolayımından geçen bir toplumsal ilişki" olarak tanımlamaktadır. Gösteri evreninde "görünen şey iyidir, iyi olan şey görünür" (Debord 1996, s. 16). Sartori (2006, ss. 24-25; Ayan 2016, s. 71); içinde yaşadığımız çağın görme ve görüntü iktidarı ile biçimlendiğini ifade etmektedir. Ona göre teknoloji çağının ışıltılı araçları "düşünen insanı" yani homo sapiens'i ortadan kaldırıp onun yerine "gören insanı" yani homovidens'ı ortaya çıkarmıştır. Sosyal medya özellikle de Instagram görmenin, göstermenin ve gözetimin öne çıktığı bir platform olması sebebiyle "gören insanın" giderek yaygınlaşmasına sebebiyet vermiştir.

Gösteri, birikim aşamasındaki sermaye olarak muhafaza edilmekte ve zamanla imaj halini almaktadır (Debord 1996, s. 23). Sosyal paylaşım platformlarında yediklerinin ve içtiklerinin, gezip gördüğü yerlerin, entelektüel birikiminin ve hatta bedeninin gösterisini yapan kullanıcılar stalk evreninde görünüme açık olan her paylaşımla kendi sosyal sermayesini kurmaktadır. Artık çok başarılı olmak, çok zengin olmak, çok iyi yerleri gezip görmek, çok sevmek ve sevilmek birey için başkaları tarafından bilindiği ölçüde önemli ve kıymetlidir; çünkü ancak bilinirse bireylerin gözünde sermaye getirisi olmaktadır. Bu sermaye bireyin kendi öz benliğini diğer kullanıcılara yani stalkerlara sunmasına yönelik bir dizi gösterinin sermayesidir.

Kullanıcılar gerçekte olmak istedikleri bireyler gibi görünebilmek için sosyal paylaşım ağlarında benliklerini yeniden inşa ederek sunmakta ve stalkerlara kendileri hakkında fikirler vermektedir. Sanal benini arzuladığı gibi kurgulayan bireyler; kendileri hakkında bilgiler yayan, takipçilerine/arkadaşlarına kendi benliği ile ilgili veri akışı sağlayan, özel hayatını açan paylaşımlar aracılığıyla kimi zaman gösterisini yapmakta kimi zamansa fikir ve görüşleriyle, eleştirileriyle onaylanmayı ve desteklenmeyi beklemektedir. Yaptığı paylaşımlar görüldüğünde, beğenildiğinde ve yorumlandığında Goffman'ın kavramsallaştırdığı biçimiyle "performansının" başarıya ulaştığını düşünen birey; tatmin olmaya başlamakta ve inşa ettiği benlik ile sosyal sermayesini sürdürmeye 
çalışmaktadır (Akmeşe 2017, s. 28). Özellikle fotoğraf paylaşımını destekleyen Instagram gibi sosyal paylaşım ağları fotoğrafın kişiler arasında önemli bir sohbet ve paylaşım aracı haline gelmesini sağlamıştır. Bireyler yaptıkları paylaşımlar ile bir yandan benlik performanslarını sergilerken diğer yandan fotoğraflarının beğenilmesini ve yorumlanmasını isteyerek iletişimini sürdürmeyi arzulamaktadır. Bu mecrada görme yani stalklama faaliyeti ise çok sevilen, beğenilen paylaşımları tespit etme ve sonrasında yapılacak paylaşımlar için örnek bulma isteğini içermektedir (Ayan 2016, s. 72). O halde yeni medya teknolojilerinin sosyal sermaye bağları üzerinde salt olumlu etkiler bıraktığını söylemek yerine eleştirel bir yaklaşım benimseyerek hem daha çok sesli bir iletişim imkanı sağladığını hem de modern insanın sosyal sermaye bağlarının giderek zayıfladığı ve bireylerin giderek yalnızlaştığı bir gösteri evrenine sebebiyet verdiğini söylemek yerinde olacaktır.

Sosyal sermaye ilk olarak bireyin ilişki ağının gelişmesine, daha sonra da ekonomik, kültürel ve sembolik sermayesinin kapsamına bağlıdır. Toplumu meydana getiren her birey bir sosyal sermayeye vâkıftır. Bu vâkıf olma durumu bireyin bir aileye, gruba, partiye, derneğe vs. ait olmasıyla ilintilidir. Bireyler bu aidiyetle grubun ağları ile kaynaklarını kullanma hakkına sahip olmaktadır. Dolayısıyla bu aidiyet bireyler için tanıma ve tanınma ile ilerleyen karşılıklılık ilişkisi içindeki sürece işaret etmektedir. Bourdieu'nun "kredi değerliliği" olarak tanımladığı bu süreç; bireylerin sosyal yaşam içinde bir statüye erişmek için sahip olması gereken kredi notlarına işaret etmektedir. Bu bağlamda Bourdieu armağanlaşmayı ileriye dönük sağlam bir yatırım olarak tanımlamaktadır (Yarcı 2011, ss. 131-132). Bu noktadan itibaren armağanlaşma teorisinden yola çıkarak sosyal medyada sürdürülen ağ iletişimini ve sosyal, ekonomik ve kültürel sermayeyi alımlamak daha anlaşılır olacaktır.

\section{Armağan Ekonomisi (Gift Economy)}

Sosyolog Marcel Mauss (2018) Polinezya, Melanezya ve Kuzey Amerika'daki arkaik kabilelerde para kavramının olmadığı bir dönemde değiş-tokuş üzerinden ilerleyen ekonomik sistemi armağanlaşma ile açıklamıştır. Armağan ekonomisi paranın olmadığı arkaik dönemde kabileler arasında değiş-tokuşu teşvik etmek amacıyla "potlaç" adı verilen festivaller üzerinden açıklanabilir. Paranın olmadığı bir evrende intiyaçların satın alınabilmesi için potlaç festivallerinin düzenlendiği bir ekonomi evreni yaratılmıştır. Potlaç törenlerinde biriktirmenin ve saklamanın lanet olduğuna inanılmış ve değiş-tokuş teşvik edilmiştir. Potlaçlar, artı ürün birikimini önlemek, eldeki fazlalığı toplumla paylaşarak hem toplumun bütünlüğünün hem de göçebe yaşamın kolaylaşmasını sağlamak için yapılan törenlerdir. Bir kabile önderinin potlaç festivaline davetinin yani değiş-tokuş ekonomisine çağrısının reddedilmesi ise savaş ilanı olarak kabul edilmiştir. Bununla birlikte potlaç törenleri kabileler arasında harcama yarışına dönüşmüş ve bu festival kabileler için sosyal statünün göstergesi olarak görülmüştür. Zeitlyn'e göre potlaç töreninde başarılı armağanlar verenlerin cömert olduğu algısı oluşmuş ve bu yolla şöhretlerini arttırma fırsatı bulmuşlardır. Şöhretini arttıranlar ise toplum nezdinde sosyal ve sembolik sermayelerini kökleştirme imkanı bulmuştur (aktaran Şen ve Çiftçi 2017, s. 360). 
Armağanlaşma teorisi üzerine kafa yoran Malinowski, Birinci Dünya Harbi'nde Trobriandlıların ağır koşullar altında çok uzun mesafeli bir deniz yolculuğu yaparak gittikleri yerdeki yerlilere verdikleri ve ileride geri döneceğinden emin olmadıkları değerli şeyleri vermelerini bir armağanlaşma olarak tanımlamıştır. Malinowski'nin bu fikri daha sonra Mauss tarafından eleştirilmiştir. Mauss, armağanlaşmanın çıkar beklemeksizin yapılan şeyler gibi görünse de asłında tamamen çıkar odaklı olduğunu ifade ederek literatüre önemli katkılar sağlamıştır (aktaran Saka 2015, s. 38).

Mauss'a göre (1988) armağan ekonomisinde hediye olan şey sadece maddi karşılığı olan şeyler değil aynı zamanda kişiler arasında gerçekleşen ilişkilerdir. Mauss için bir armağan, daha salt parasal ya da maddi ilişkilerden ayrı olarak, toplumsalın bir parçası olarak işlenen, faydacı ya da gereksiz herhangi bir nesne ya da hizmettir. Bu, geleneksel bir kullanımdan uzaklaşsa da, normalde bir hediye olmamasına rağmen, bir hediyelik (emtia olabildiği gibi) olabilen emeği içerdiği için genel kullanımdan ayrılır (Carrier 1991, s. 122). Cheal da (1988) piyasada mal ve hizmetlerin yani ticari değerlerin varlığı bulunmakta iken armağanlaşma geleneğinde duygusal değerlerin dolaşımının söz konusu olduğunu ifade etmiştir (Godbout 2000, s. 53). İşte bu emek ya da duygusal değerler sebebiyle Mauss'a göre alış ve satış işlemleri resmi olarak serbestken, armağan işlemleri özel olsa da zorunludur. Mauss,un klasik formülasyonunda, bir armağan ilişkisinin tarafları hediyeyi geri verme zorunluluğu, hediye verme ve bunları alma yükümlülüğü altındadır. Bu yükümlülükleri reddetmek, diğer tarafla sosyal ilişki ve dolayısıyla kamu beklentilerini ve özel inancını ihlal etmek anlamına gelir. Simmel, Mauss'un bahsettiği bu zorunluluğun özgür olmamaktan ziyade fayda sağlamak için gerekli olan etik zorunluluk anlamına geldiğini ifade etmektedir (Mauss 1969, ss. 1011; Carrier 1991, s. 123). Bourdieu da ritüel haline gelerek sosyo ekonomik bağlamdan koparılan armağanlaşmanın esasında bir stratejiler bütünü olduğunu dile getirmiştir (Saka 2015, s. 39).

Armağanlaşma teorisi üzerine kafa yoranların kimisi bu kavramı olumlu bir terim olarak ele alırken kimi araştırmacılar ise kavrama eleştirel bir tavırla yaklaşmaktadır. Armağan ekonomisine olumlu yaklaşanlar bu ekonomiyi önceden belirlenmiş bir karşılığa dayanmayan alışveriş/değiş-tokuş ilişkisi olarak tanımlamaktadır. Birisi size herhangi bir ürün, hizmet, arkadaşlık vs. sunduğunda, anlaşmayla bunun belli bir karşılığı önceden belirlenmez. Buna göre ürünü, hizmeti, belki ağlanacak omzu alan siz, bunun sonucunda hissettiğiniz şükran karşılığında o kişiye bir karşılık vermek isterseniz, kalbinizden gelen her ne ise onu iletirsiniz. İşte bu armağan ekonomisi sosyal ilişkiler bağlamında düşünüldüğünde kişiler arasında değiş tokuşlarla ilerlemektedir (Ertegün 2014). Sosyal ilişkileri sürdürmek amacıyla yürütülen değiş-tokuş yani armağanlaşmanın ise ne derece olumlu olduğu konusu tartışmalıdır.

Değiş-tokuş ile ilerleyen armağan ekonomisi sosyal medya üzerinden sürdürülen ilişkiler düşünüldüğünde sosyal medya platformlarının bireylerin hayatında değiştokuş makinesi olarak var olduğu söylenebilir. Sosyal sermaye bir gruptaki üyelik statüsüyle ilişkilidir ve grup üyeleri arasında armağan ekonomisinden kaynaklanan maddi ve sembolik değişimlerle var olabilecek ilişkilerdir (Şen ve Çiftçi 2017, s. 360). 
Sosyal medya aracılığıyla yaratılan sembolik sermaye hediye değişimi sayesinde sonsuz miktarda yeniden üretilir. Kullanıcılar yaptıkları paylaşım, beğeni ve yorum gibi iletişimsel faaliyetlerinin her biri armağan olarak var olmakta ve bireye sosyal bağlar kazandırmaktadır. Sosyal medyada bir kullanıcı yaptığı beğeni ve yorumlarla kısa vadede karşılık beklemiyor gibi görünse de ileride yapacağı paylaşımların beğeni teminatını yani sosyal ağlar aracılığıyla sürdürdüğü iletişimsel faaliyetlerini sağlama almış olmaktadır. Sosyal ağlarda herkesten bağımsız var olabilmek tıpkı gerçek hayatta da olduğu üzere olanaksızdır. Bireyler bir topluluğa ait olma hissiyle sosyal ağlarda paylaşım, beğeni ya da yorum yapmak gibi etkileşimsel faaliyetlerde bulunmaktadır. Bu etkileşimsel faaliyetler kısa vadede karşılıklııı ilkesinden uzak görünse bile kullanıcının sosyal, kültürel ve ekonomik sermayesinin garantörü olmaktadır. Uzun vadede ise sosyal ağlardaki iletişimsel faaliyetlere "kullanıcılar nezdinde" olumlu geri dönüşler şeklinde yansımaktadır. Birey eğer ki sosyal medyanın armağan ekonomisinde işleyen bir dişli olmayı kabul etmez ise armağan ekonomisinin getireceği sosyal sermayeden yoksun kalmayı da kabullenmiş olacaktır.

Howard Rheingold armağan ekonomisini internet ağının merkezine alarak internetin en değerli para biriminin enformasyon olduğunu söyler (Saka 2015, s. 39). Buna göre sosyal ağlarda birey kabul görmek istiyorsa öncelikle nasıl kabul göreceğinin bilgisini edinmeli daha sonra da bu enformasyonu diğer kullanıcılara yayabilmelidir. İşte bu amaçla birey evvela stalklama yapmak durumundadır. Tanınmış bir kişinin ya da fenomen olmuş bir hesabın paylaşımlarını stalklamak o hesapları taklit etmenin ilk adımı olacaktır. Burada taklit, basit bir özentiden ayrı olarak stalklama ile gelen enformasyonun getirdiği sosyal, kültürel ve ekonomik sermayenin aracısıdır. Örneğin pek çok kullanıcının X isimli ünlü ve gösterişli bir mekanda yaptığı paylaşımları gören kullanıcı o kullanıcılarla aynı gruba ait olduğunu göstermek için X mekana gidecek ve aynı fotoğraf pozunu paylaşacaktır. Böylelikle birey hem o gruba ait olduğu hissini doyumsayacak hem de diğer stalkerlara aynı grupta olmak için yapmaları gerekenler konusunda fikirler sunacaktır. Birey için başkaları tarafından görülmek, izlenmek, takip edilmek ya da beğeni almak kişisel benliği tatmin eden, ekonomik, sosyal ve kültürel sermayeyi güçlendiren bir armağandır. Bu sebeple sosyal paylaşım ağlarında bilhassa da fotoğraf paylaşımını destekleyen Instagram gibi paylaşım ağlarında etkileşime izin vererek sosyal sermayeyi desteklemeye ortam hazırlayan beğeni butonları, emojiler, yorum imkanları sosyal ilişkiler düzeyinde ilerleyen armağan ekonomisini kökleştirmektedir. Bu ekonomi sosyal ağlarda da karşılıklılık ilkesinden hareketle kökleşmekte; yapılan beğeni, yorum gibi her etkileşimsel faaliyetin ilerleyen zaman diliminde kullanıcıların kendi hesaplarına dönüşü yani armağanı olması arzulanmaktadır. Yine sevdiği bir sanatçı veya politikacının yaptığı paylaşımları destekleyen bireyler ait oldukları grup içinde karşılıklılık zemini üzerinden ilerleyen iletişimlerini dolayısıyla sosyal, kültürel ve ekonomik sermayelerini sürdürüyor olacaktır. İşte bu sermaye bilgisine dair yayılan enformasyonun dolaşımı internet ortamındaki armağan ilişkisinin yani iletişimin değiştokuşunun göstergesi olmaktadır. 


\section{Armağan Ekonomisi ve Sosyal Sermaye Kapsamında Instagram}

Çalışmanın teorik kısmını desteklemek amacıyla Instagram hesabını farklı amaçlar doğrultusunda kullanan beş farklı hesabın son üç ay içerisindeki paylaşımları katııımcı gözlem yoluyla izlenmiş ve sosyal sermaye ve armağan ekonomisi üzerinden stalk bağlamında genel bir değerlendirme yapılmıştır. Instagram toplumun her katmanından insan tarafından farklı amaçlarla kullanılan bir sosyal paylaşım ağıdır. Kimileri sosyal paylaşım ağı olarak Instagram'ı yaşam tarzının bir gösteri aracı olarak kullanmakta, kimileri toplum tarafından kabul görmüş insanlar olarak entelektüel birikiminin sermaye aracı olarak değerlendirmekte, kimileri ise dünyayı algılama biçimiyle kendi görüş ve ideolojisini tüm kullanıcılara duyurarak farkındalık yaratma amacıyla kullanmaktadır. Instagram'ın bu çok yönlü kullanımında merkezde yer alan stalk kavramının sosyal sermaye ve armağan ilişkisi bağlamında kapsamlı bir biçimde değerlendirilebilmesi için çalışmada sosyal medyayı aynı amaçlar için kullanan farklı hesapları gözlemlemek yerine bir siyasetçi, bir sanatçı, bir aktivist, bir fenomen ve son olarak bir de yaşam tarzıyla imrenilen bir ünlünün hesabı üç ay süre ile gözlemlenmiştir. Sosyal medyayı farklı amaçlarla kullanan insanların sosyal sermayelerini hangi kullanım biçimleriyle kurdukları, bu inşa sürecinde stalkerlara hangi mesajları ilettiği ve tüm bunların sosyal ağlar üzerinden ilerleyen armağan ilişkilerine nasıl yön verdiği gözler önüne serilmiştir.

\subsection{Muharrem İnce Örneği}

Demokratik bir toplumda bireylerin sosyal ağlar üzerinden siyasal partilere ya da kişilere destek vermesi, sosyal ağlar üzerinden gerçekleştirilen ya da desteklenen faaliyetlere katılımda bulunması gönülülük esasıyla ilerleyen armağan ilişkisini temsil eder. Söz konusu sivil toplum, demokrasi, aktif vatandaşlık gibi kavramlar olduğunda sosyal medyanın armağanlaşma ilişkisinin sosyal sermayelerin sürdürülmesinde hatta ekonomik sermayeye dönüştürülmesinde son derece faydalı olduğu söylenebilir. Çalışma kapsamında gözlemlenen, Instagram hesabını aktif biçimde kullanan CHP Yalova milletvekili ve 2018 Cumhurbaşkanlığı seçimlerinde CHP'nin adayı olan Muharrem İnce'nin 11.07.2018 tarihi itibariyle bir milyon yedi yüz bin civarı takipçisi bulunmaktadır. Özellikle partisinin cumhurbaşkanı adayı olduktan sonra sosyal medya hesabını aktif bir biçimde kullanmaya başlayan İnce'nin Instagram hesabını ağ kurma ve siyasal destek oluşturma amacıyla kullandığı görülmektedir. İnce, Fizik öğretmeni olduğunu hatırlatan paylaşımlar yaparak ve her fırsatta eğitime, akıl ve bilime dayalı bir toplum inşa edeceğine dair vaatlerde bulunarak kültürel sermayesini sosyal medya kullanıcılarıyla bağ kurmak ve ekonomik sermayeye dönüştürmek amacıyla kullanmaktadır. İnce'nin bu paylaşımlarını beğenen, onu takip eden kullanıcılar internet ağı üzerinden kültürel sermayenin değiş tokuşunu sağlamaktadır. İnce'nin hesabı üzerinden siyasal kampanya süresince düzenlediği mitinglerden yığınlar halindeki kalabalık görüntülerini paylaşması, kendisini destekleyen insanlarla sosyal sermaye bağlarını kuvvetlendirmesini sağlamakta; onu stalklayan kullanıcılar için ise kendileri gibi düşünenlerin bir arada olduğu bir topluluğa üye olma hissini uyandırmaktadır. İnce'nin paylaşımlarına yapılan her beğeni armağan ilişkisinin sürekliliğini destekleyerek diğer sermaye türleriyle birlikte var olan sosyal sermaye bağlarını sağlamlaştırmaktadır. 


\subsection{Feminizm_tr Örneği}

Politik çıkarlar, demokratik haklar bağlamında kullanımı son derece yaygın olan sosyal medya aktivist bireyler için de elverişli bir ortam sağlayabilmektedir. Çalışma kapsamında gözlemlenen feminizm_tr isimli anonim hesabın 30.07.2018 tarihi itibariyle 297 bin takipçisi bulunmaktadır. Instagram profilini aktif biçimde kullanan anonim hesabın paylaşımlarının ortak paydası feminizm konusunda internet ağı üzerinden farkındalık yaratılmasını sağlamak ve toplumu bilinçlendirmektir. Feminizm_ tr hesabı üzerinden toplumsal cinsiyet rollerine karşı çıkan paylaşımlar, ülkemizde meydana gelen cinsiyetçi olay ve durumlar ile fiziksel, psikolojik ve cinsel şiddet içeren her türlü eylemin (taciz, tecavüz, öldürme, yaralama, eğitim gibi en temel haklardan mahrum bırakma vs.) duyurusu yapılarak Instagram ağı üzerinden toplumun bilinçlendirilmesi amaçlanmaktadır. Bununla birlikte hesap üzerinden feminizmin ne olduğu ve ne olmadığına yönelik içerikler paylaşılarak feminizm savunularının topluma kazandırılması hedeflenmektedir. Öte yandan toplumsal cinsiyet rollerini altüst eden paylaşımların yapıldığı anonim hesap üzerinden ırkçılık karşıtı, hayvan haklarını savunan tarzda paylaşımlar da yapıldığı görülmektedir. Hatırı sayılır oranda takipçisi bulunan hesabın reklam paylaşımları da yaparak sosyal sermayesini ekonomik sermayeye bağladığı görülmektedir. Dijital aktivizmin başarılı bir örneğini oluşturan feminizm_tr cinsiyet eşitliğinden yana olanların takip ettiği, kendisini ait hissettiği bir mecra sunması sebebiyle sosyal sermaye bağlarını güçlendirmektedir. Bireyler bu hesap üzerinden bilinçlenecek ya da yalnız olmadığını duyumsayacak; ileride meydana gelebilecek olan cinsiyetçi, şiddet içerikli olayları önlemek adına birlik ruhu oluşturabilecektir. Aktivist paylaşımlarla öne çıkan hesabı takip eden ya da stalklayanlar kültürel anlamda bilinçlenerek ya da kendisi gibi düşünenlerin var olduğu bir alana üye olmanın mutluluğunu yaşayarak sosyal ve kültürel sermayelerini kurmuş olmaktadır. $\mathrm{Bu}$ durum ise armağanlaşma teorisine olumlu yaklaşanların bakış açısını destekler nitelikteki bir toplumsal değişime işaret etmektedir. Kullanıcılar arasında sürdürülen siber iletişim aracılığıyla armağan ilişkisi döngüsü sürüp gitmekte hatta değişime yönelik umut tohumları ekilebilmektedir.

\subsection{Sunay Akın Örneği}

Çalışma kapsamında Instagram hesabı gözlemlenen Sunay Akın'ın Instagram hesabında 30.07.2018 tarihi itibariyle 632 bin takipçisi bulunmaktadır. Türkiye'nin başarılı şair, yazar ve tiyatro oyuncularından biri olan Akın aydın bir sanatçı örneğini teşkil eder. Sosyal medya kanalları toplum nezdinde saygınlığı olan bireyler için de önemli birer iletişim ve sermaye aracı olabilmektedir. Sunay Akın da sosyal ve kültürel sermayesini sosyal ağlar aracılığıyla sağlamlaştıran ülkemiz aydınlarından biri olarak Instagram hesabını aktif biçimde kullanmaktadır.

Başarılı sanatçı sosyal medya hesabından gerçekleşmiş ya da yakın zaman içinde gerçekleşecek imza günlerinin, konser ve oyunlarının duyuru ve haberlerini yaparak kendi kültürel, sosyal ve ekonomik sermayesini sağlamlaştırmaktadır. Akın'ın edebiyat, resim gibi sanat kollarının önemli eserlerine atıfta bulunan paylaşımlar yaparak kültürel 
sermayesi aracılığıyla takipçileriyle bağ kurduğu görülmektedir. Sanatçının kültür ve sanat içerikli paylaşımlarına çokça beğeni ve olumlu yorum alması sosyal paylaşım ağında armağan ilişkisinin sürekliliğini desteklemektedir. Sanatçıyı takip eden ve paylaşımlarını beğenen kullanıcılar da aynı kültürel ve sosyal sermayeyi kendilerine armağan olacak şekilde kullanmaktadır. Özetle Akın, Bourdieu'nun saygınlığın ve onurluluğun sermayesi olarak tanımladığı sosyal sermayeyi kişisel hesabı aracılığıyla sağlamlaştıran kullanım tarzıyla dikkat çekmekte ve diğer kullanıcılarla paylaşım üzerinden ilerleyen armağan ilişkisini sürdürmektedir.

\section{4. Șeyma Subașı Örneği}

Söz konusu demokratik haklar, sivil katılım, özgürlükler vs. olduğunda kullanıcıların sermayelerini inşa etme ve güçlendirmede aracı olarak kullandıkları sosyal medya politik amaçlar dışında kullanıldığında her zaman aynı olumlu etkileri göstermez. Çalışma kapsamında stalklanan, Instagram üzerinden paylaştığı fotoğraflar ile fenomen haline gelen, televizyoncu Acun Ilıcalı'nın eşi Şeyma Subaşı'nın hesabı sosyal medyanın politik amaçlar dışında kullanımını açıklamada yardımcı olarak kullanılabilir. Instagram hesabında 12.07.2018 tarihi itibariyle 2 milyon 800 bin takipçisi bulunan Şeyma Subaşı, sosyal medyayı kullanım tarzıyla diğer kullanıcılar yani stalkerlar için ideal olanı temsil etmektedir. Yaşamının önemli çoğunluğunu gezerek geçiren Subaşı gezip gördüğü yerler, giyim-kuşam, eğlence biçimleri vs. aracılığıyla kültürel ve ekonomik sermayesini kullanarak sosyal sermayesini inşa etmektedir. Çalışmadan, lüks giyinip kuşanarak ve dünyayı gezerek geçirilen bir hayata imrenen stalkerlar için Subaşı ideal bir dikizleme nesnesi haline gelmektedir. Subaşı gibi olmak isteyen, onun yaşamına imrenen kullanıcılar onu açıkça takip ederek ya da gizliden stalklayarak aynı kültürel, ekonomik ve sosyal sermayeye erişebilmenin ve bu yolla sanal benliğini inşa etmenin yollarını aramaktadır. Bu yollar elbette ki onun çektiği gibi fotoğraflar çekilmekten, giyimkuşam tarzını taklit etmekten, onun eğlence ve mutluluk anlayışını benimsemekten geçmektedir. Böylelikle tüm Instagram kullanıcıları arasında benimsenen, kültürel ve ekonomik sermayelerin birbiri içinde eridiği bir değiş-tokuş evreni yani armağan ilişkisi ortaya çıkmaktadır. Fotoğraf meraklılarının çektikleri fotoğrafları paylaşarak ortak bir ilgi alanında buluşmalarını kolaylaştırmak amacıyla kurulan Instagram'ın bugün almış olduğu teşhirci ve hazcı vaziyet, gösteri evreni üzerinden sermayelerin inşa edildiği armağan ilişkilerinin her zaman olumlu sonuçlar vermediğini gözler önüne sermektedir.

\subsection{Social Mom Örneği}

Çalışma kapsamında gözlemlenen Social Mom isimli Çağla Düvenci Sönmez'in Instagram üzerinde 12.07.2018 tarihi itibariyle 423 bin takipçisi bulunmaktadır. Düvenci anne-bebek-sosyal yaşam üçgeni etrafında şekillendirdiği hesabını kullanım tarzıyla diğer iki gözlem örneğinden bir noktada ayrılmaktadır. Kendisine taktığı tilt isimle Social Mom, Instagram hesabı üzerinden kendi fotoğraflarının yanı sıra eşinin, çocuklarının yani mutlu aile yaşantısına ait fotoğraf karelerinin paylaşımını yapmaktadır. Social Mom yakın zaman öncesine kadar bir vakıf üniversitesinin psikoloji-sosyoloji bölümünden mezun olduğunu söyleyerek bu unvanla televizyon programlarına katılıp, birçok 
ünlü firmaya ait ürünün tanıtımını yapmış ancak gerçekte psikolog ya da sosyolog olmadığı ortaya çıkınca Instagram hesabındaki mesleki unvan ibaresini kaldırmıştır (http://www.medyafaresi.com/foto-galeri/unlu-psikolog-sahte-cikti/800465 , 21 Aralık 2016). O unvanla sosyal ve ekonomik sermayesini inşa eden Düvenci'nin bugün de kişisel hesabından kendisini ve küçük kızını giydiren marka ve butiklerin reklamlarını yaptığı gözlemlenmektedir. Özellikle bebeği üzerinden kurguladığı anne kimliğiyle Düvenci'nin çocuklarını ekonomik birer sermaye olarak kullandığı görülmektedir. Sık sık çocuklarıyla vakit geçirdiği, gezdiği, tatil yaptığı anların görüntülerini paylaşan Social Mom'un daha çok kendisi gibi anne olan sosyal medya kullanıcıları tarafından takip edildiği ve onlarla etkileşim halinde olmaya yönelik paylaşımlarda bulunduğu görülmektedir. Social Mom; genç, çocuk sahibi ancak yine de fit görünümlü, bakımlı yani ideal anne kimliği üzerinden kurguladığı gösteri evreninde anne olan sosyal medya kullanıcıları için idol olabilecek bir dikizlik nesnedir. Social Mom'un Instagram paylaşımlarını gözlemleyen pek çok kullanıcı stalk avında ele geçirdiği bilgileri daha sonra kendi hesabında taklit etmek üzere hafızasına kaydetmektedir. Bu durum Bourdieu'nun stratejiler bütünü olarak tanımladığı armağanlaşma teorisinde sosyal medya beğenilerinin ve takipleşmelerinin çıkar anlayışına işaret etmektedir. Böylelikle Instagram kullanıcıları arasında yayılan, sosyal sermayelerin var ettiği bir armağan ilişkisi döngüsü sürüp gitmektedir.

\section{Sonuç}

Gün geçtikçe insan hayatındaki hakimiyeti daha da artan sosyal medya etkileșime açık, kullanıcı tabanlı yapısıyla bireylerin sosyal, kültürel ve ekonomik sermayelerini kurmasının mecrası haline gelmiştir. Bireylerin düşüncelerini dile getirme, kamuoyu oluşturma, kendisi gibi düşünen bireylerle aynı havuzda yer alma amaçlarıyla bulunduğu bu mecra sosyal, kültürel ve ekonomik sermayelerin kurulmasında çağdaş bir iletişim ortamı sunmaktadır. Dijital iz sürmenin merkezde yer aldığı bu ilişki biçimi kimi zaman toplumu ilgilendiren siyasal olaylar karşısında aynı fikirde olan kullanıcıların birbirlerine destek olduğu, aidiyet duygusunu deneyimlediği bir çember oluşturarak armağanlaşma teorisinin olumlu yanını ortaya koymaktadır. Çalışma kapsamında incelenen hesaplardan Muharrem İnce, Sunay Akın ve Feminizm_tr örnekleri internet ağında fikirler aracılığıyla kurulan sosyal sermaye bağlarının güçlü armağan çemberleri oluşturduğunu gözler önüne sermektedir. Geleneksel medyanın içinde kendine yer bulamayan ya da hali hazırda mevcut sermaye bağlarını güçlendirmek isteyenler için sosyal paylaşım ağları armağan ilişkileri kurulabilecek alternatif mecralardır. Ancak yine de Bourdieu'nun dediği gibi seçkin kimseler için önemli bir avantaj olan sosyal sermaye kullanıcı tabanlı sosyal paylaşım ağlarında diğer kullanıcılar için her zaman aynı sonucu vermeyecektir. Şüphesiz sosyal paylaşım ağları aracılığıyla sermaye bağlarını güçlendirmek isteyen herkes Muharrem İnce ya da Sunay Akın kadar tanınmış değildir. Ancak yine Feminizm_tr örneğinde olduğu gibi bireysel hesaplar yerine anonim hesap kullanma yoluyla da fikirler dolaşıma sokulabilmektedir.

Toplumu ilgilendiren siyasal olaylar dışında sosyal medya bireysel kimliklerin inşa edildiği yeni bir iletişim evreni yaratarak Bourdieu'nun deyimiyle "kredi değerliliği” üzerinden 
ilerleyen, gösteriyi doğallaştıran bir dünya yaratmaktadır. Çalışma kapsamında gözlemlenen hesaplardan Şeyma Subaşı ve Social Mom hesapları gösteri üzerinden ilerleyen stalk evreninin trajik yanını ortaya koymaktadır. Sosyal ilişkilerini, ekonomik, kültürel ve sosyal sermayelerini kurmak ya da gösterişe açmak için sosyal paylaşım ağlarını kullanan bireyler teşhir tabanlı fotoğraf ağı olan Instagram'da stalklayan ya da stalklanan olarak armağan ilişkisine hayat vermektedir. Bu dünyada bireyler için önemli olan tek şey onlara sermaye kazandıracak statüler edinebilmektir. Statü kazanmanın yolu kimi zaman kültürel birikimi sergilemekten, kimi zaman bedeni ya da mahrem olanı teşhir etmekten, kimi zaman ise kıskanılan durum içinde olmaktan geçmekte sonucunda ise bir sosyal sermaye kazanımı amaçlanmaktadır. Bu amaç uğruna evvela stalklayan, daha sonra stalklanan bireyler, internet ağında beğenileşmeyi ve her türlü etkileşimsel faaliyeti yani armağanlaşmayı ileriye dönük sağlam bir yatırım olarak kullanmaktadır. Dolayısıyla her şeyin meta statüsüne indirgendiği, teşhirciliğin had sayfaya ulaştığı, bireylerin kendi sosyal, kültürel ve ekonomik sermayelerini inşa etmek için kullandıkları sosyal ağlardaki armağan ilişkisine salt demokratik haklar ve ifade özgürlüğü üzerinden bakmak yerine eleştirel bir bakış açısıyla temkinli yaklaşılmalıdır.

\section{Kaynakça}

Akmeşe, Z., \& Deniz, K. (2017). Stalk, Benliğin İzini Sürmek. Ege Üniversitesi Illetişim Fakültesi Yeni Düşünceler Hakemli E-Dergisi, 8, 23-32.

Ayan, G. (2016). Tüketim kültürü bağlamında kimlik inşasının sosyal medyada kullanımı: Instagram örneği. (Yayımlanmamış Yüksek Lisans Tezi), Başkent Üniversitesi Sosyal Bilimler Enstitüsü, İstanbul.

Babacan, M. E. (2012). Toplumsal Paylaşım Ağlarında Sosyal Sermaye Pratikleri. (Yayımlanmamış Doktora Tezi). Sakarya Üniversitesi Sosyal Bilimler Enstitüsü, Sakarya.

Bourdieu, P. (2010). "Sermaye Biçimleri", İçinde: M. M. Şahin ve A. Z. Ünal (Der.), Sosyal Sermaye, Değişim, ss. 45-75, İstanbul.

Boz, M., Buluk, B., \& Aysu, S. (2017). Sosyal Medya Kullanımı Ve Sosyal Sermaye İlişkisi: Çanakkale Onsekiz Mart Üniversitesi Örneği.

Carrier, J. (1991). Gifts, commodities, and social relations: A Maussian view of exchange. In Sociological forum, 6(1), 119-136. Kluwer Academic Publishers-Plenum Publishers.

Debord, G. (1996). Gösteri Toplumu. İstanbul: Ayrıntı Yayınları.

Dreßing,1 H., Klein, U., Bailer, J., Gass, P., \& Gallas, C. (2009). Cyberstalking. Der Nervenarzt, 80(7), 833-836.

Godbout, J. T. (2000). Armağan Dünyası. (Çev. D. Hattatoğlu), İstanbul: İletişim Yayınları.

Heinrich, P. A. (2015). Generation iStalk: an Examination of the prior relationship between victims of stalking and offenders.

Ling, R. (2008). New Tech, New Ties: How Mobile Communication is Reshaping Social Cohesion. Londra: The MIT Press. 
Mauss, M. (2018). Armağan Üzerine Deneme. (Çev: Nihan Özyıldııı) İstanbul: Alfa Yayıncılık. Perry, J. (2012). Digital stalking: A guide to technology risks for victims. Network for Surviving Stalking \& Women's Aid, Bristol, UK.

Phua, J., \& Jin, S. A. A. (2011). 'Finding a home away from home': The use of social networking sites by Asia-Pacific students in the United States for bridging and bonding social capital. Asian Journal of Communication, 21(5), 504-519.

Phua, J., Jin, S. V., \& Kim, J. J. (2017). Uses and gratifications of social networking sites for bridging and bonding social capital: A comparison of Facebook, Twitter, Instagram, and Snapchat. Computers in Human Behavior, 72, 115-122.

Saka, E. (2015). “Armağanlaşmadan(Gift Economy) Kitle Kaynağa(Crowdsourcing) Dijital Gönüllülükler Üzerine”, İletişim Çalışmaları içinde, Filiz Aydoğan (Ed.), İstanbul: Derin Yayınları.

Shane-Simpson, C., Manago, A., Gaggi, N., \& Gillespie-Lynch, K. (2018). Why do college students prefer Facebook, Twitter, or Instagram? Site affordances, tensions between privacy and self-expression, and implications for social capital. Computers in Human Behavior, 86, 276-288.

Sun, Y., \& Shang, R. A. (2014). The interplay between users' intraorganizational social media use and social capital. Computers in Human Behavior, 37, 334-341.

Şan, F. B. \& Çiftçi, Y. (2017). Armağan Ekonomisi Bağlamında Türkiye`de Zaman Bankacılığı Deneyimi: Zumbara Vakası. Akademik Sosyal Araştırmalar Dergisi, 5(41), 354-370.

Ünal, A. Z. (2004). Sosyal Tabakalaşma Bağlamında Pierre Bourdieu'nun Kültürel Sermaye Kavramı, Hacettepe Üniversitesi Sosyal Bilimler Enstitüsü, Doktora Tezi.

Williams, D. (2006). On and off the'Net: Scales for social capital in an online era. Journal of computer-mediated communication, 11(2), 593-628.

Yalçın, N. (2015). Sosyal medyada simgesel şiddet: Ekşi sözlük örneği: Symbolic violence on social media: Example of ekşi sözlük (Doctoral dissertation, Pamukkale Üniversitesi).

Yarcı, S. (2011). Pierre Bourdieu'da Sosyal Sermaye Kavramı. Akademik Incelemeler Dergisi, $6(1)$.

\section{INTERNET ERIŞiMLERi}

Cambridge Dictionary. https://dictionary.cambridge.org/dictionary/turkish/stalk_1 (Erişim Tarihi:20.05.2018).

Cumhuriyet Gazetesi (2016). Sosyal Medyanın Yeni Terimi: Stalklamak Nedir?. http://www. cumhuriyet.com.tr/haber/teknoloji/554962/Sosyal_Medyanin_Yeni_Terimi_Stalklamak_Nedir_. html (Erişim Tarihi:13.05.2018).

Ertegün, E. (2014). Armağan Ekonomisi 5N1K, www.yesilgazete.org. https://yesilgazete.org/ blog/2014/10/02/armagan-ekonomisi-5n1k-emre-ertegun/ (Erişim Tarihi:04.07.2018)

Oxforddictionaries.com. https://en.oxforddictionaries.com/definition/stalker (Erişim Tarihi:20.05.2018).

https://www.instagram.com/vekilince/?hl=tr (Erişim Tarihi:11.07.2018) 
https://www.instagram.com/seymasubasi/?hl=tr (Erişim Tarihi:11.07.2018)

https://www.instagram.com/socialm.o.m/?hl=tr (Erişim Tarihi:13.07.2018)

http://www.medyafaresi.com/foto-galeri/unlu-psikolog-sahte-cikti/800465

(Erişim Tarihi:13.07.2018)

https://www.instagram.com/sunay.akin/?hl=tr (Erişim Tarihi:30.07.2018)

https://www.instagram.com/feminizm_tr (Erişim Tarihi:30.07.2018) 